\title{
The Emergent Reversal of Coagulopathies Encountered in Neurosurgery and Neurology: A Technical Note
}

\author{
Joshua Eric Medow, MD, MS; Matthew R. Dierks, PharmD; Eliot Williams, MD, PhD; \\ and J. Christopher Zacko, MD, MS
}

\begin{abstract}
It is imperative for neurologists, neurosurgeons, and neurointensivists to know how to stop lifethreatening hemorrhage in both surgical and non-surgical patients. However, knowing how to medically correct a coagulopathy has become increasingly challenging as more contemporary and sophisticated anticoagulation agents are developed and prescribed. In a time-sensitive and life-threatening situation, where there is little margin for error, the neurosurgeon may not have ready access to information about the drug or condition that caused the coagulopathy or the information on how to treat it. This thorough review of the literature provides a comprehensive overview of the medications and conditions that can lead to persistent and/or life-threatening intracranial hemorrhage.
\end{abstract}

Keywords: Anticoagulants; Coagulopathy; Intracerebral hemorrhage; Neurosurgery; Reversal

$\mathrm{R}$ neurosurgeons, above any other medical subspecialists, need to understand how to effectively stop life-threatening hemorrhage. That said, knowing how to medically correct a coagulopathy has become increasingly challenging as more contemporary and sophisticated anticoagulation agents are developed and prescribed. These newer agents not only broaden the store of knowledge required to treat these patients, but they also make it more difficult to achieve an effective reversal with each new generation of drugs that arrive on the market. When faced with a life-threatening coagulopathy, neurosurgeons and neurologists may not have ready access to information about the drug or condition that caused the coagulopathy or the information on how to treat it.

This technical note is a comprehensive overview of the medications and conditions that can lead to persistent (or initiation of) life-threatening intracranial hemorrhage. It is

Corresponding Author: Joshua Medow MD, MS; Assistant Professor of Neurosurgery and Biomedical Engineering; Department of Neurosurgery University of Wisconsin Hospital and Clinics; Room K4/822; 600 Highland Avenue; Madison, WI 53792-000I; Phone: (608) 263-0485; Fax: (608) 263-I728; Email: medow@neurosurgery.wisc.edu compiled into nine tables that are organized by the mechanism of coagulopathy. It documents: (a) the duration of action of the offending agent or condition; (b) the treatment; (c) the half-life of the treatment; and (d) the laboratory tests needed (if available) to follow the reversal of the coagulopathy. By design, the text has been kept to a minimum, and the tables made succinct to most practically present the relevant information.

\section{Methods}

A comprehensive review of the literature including a PubMed search from 1966 to April 2014 and a Google scholar search was performed, and pertinent articles were reviewed and cited. Additional information from online medical sources were reviewed and cited as well.

\section{Results}

The tables provided in this article review key information about the medical conditions and drugs used to cause various coagulopathies. Reversal agent options are specifically

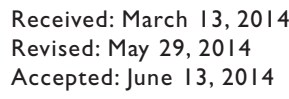


named and their half-lives are reported (for patients presumed to be without end-stage organ failure). The tables provide:

- Doses of reversal agents for adult patients

- The agents listed in order of preference

- Pediatric patient data was not compiled in these tables

- Associated laboratory tests that may be useful

- The levels of evidence offered are based on the University of Wisconsin Health Care (UWHC) Guidelines that follow criteria used by the American College of Cardiology and the American Heart Association (ACC/AHA).

Table 1 reviews those agents that indirectly affect thrombin (generally through antithrombin) and include drugs such as the heparinoids and their reversal agents. ${ }^{1,2}$ Heparin will potentiate the action of antithrombin III and thereby inactivates thrombin (as well as activated coagulation factors IX, X, XI, XII, and plasmin) and prevents the conversion of fibrinogen to fibrin. Therefore, thrombosis is blocked through the inactivation of activated Factor $\mathrm{X}$ and inhibition of prothrombin's conversion to thrombin. Unfractionated heparin binds to antithrombin III (ATIII) at the site of the native pentasaccharide sequence, changing its conformation and converting it from a slow to a rapid inactivator of several coagulation factors, particularly factor Xa. However, in order to inactivate thrombin, heparin must bind to thrombin and AT simultaneously, an effect that occurs only when the molecule exceeds 18 monosaccharide units (greater than 6000 daltons). Low molecular weight heparins (LMWHs) have a similar mechanism of action of heparin and retain the ability to inactivate factor Xa. However, because they are smaller molecules, they cannot simultaneously bind to thrombin and AT and, therefore, have a lesser effect on thrombin. Fondaparinux causes an antithrombin III-mediated selective inhibition of only factor $\mathrm{Xa}$, but cannot inactivate thrombin because of its extremely short length. It contains only a sulfated pentasaccharide unit with higher antithrombin affinity than the native pentasaccharide seen with unfractionated heparin.

The recommended laboratory tests to assess efficacy of each of these agents is as follows: activated partial thromboplastin time (aPTT) and/or activated clotting time (ACT) to measure heparin activity and anti-factor Xa +/- ACT to assess LMWH and fondaparinux activity. Protamine is the most commonly recommended reversal agent for heparin and LMWH. That said, protamine has not been shown to be successful in reversing fondaparinux. In severe cases, one could consider also giving Factor VIIa in an attempt to reverse severe bleeding after administration of fondaparinux. ${ }^{3}$

Table 2 lists the newest class of anticoagulants, the direct Factor Xa inhibitors. ${ }^{1,4}$ They differ from the agents in table 1 in that they do not require a cofactor (eg. ATIII) for activity and are considered direct Factor Xa inhibitors. While some practitioners will estimate drug activity with anti-factor $\mathrm{Xa}$ levels, it is important to emphasize that no therapeutic laboratory monitoring has been established. In mild to moderate cases of hemorrhage, it is advised to give 20-30 units/kg of prothrombin complex concentrate (PCC), while $40-50$ units $/ \mathrm{kg}$ should be given if bleeding is severe. While availability of PCCs varies among institutions, the authors advocate for the use of 4-factor PCCs over 3-factor PCC, if given the choice. There are ongoing efforts to develop reversal agents and effective treatment strategies for this class of anticoagulant. ${ }^{5}$

Table 3 reviews those agents that directly impact thrombin and includes some of the newer drugs such as dabigatran. ${ }^{1,4,6,7}$ There are no antidotes to these drugs at this time, but some are under development. There is also no reliable laboratory test to directly measure the extent of anticoagulation. Until such antidotes become available, 4-factor PCCs and 3-factor PCCs are recommended as an effective treatment strategy (although admittedly, the literature has some variation depending on the specific direct thrombin inhibitor used ${ }^{4,8}$ ). Some have advocated for the use of activated charcoal if the patient recently took a dose of the medication. ${ }^{9}$ Another agent, factor eight inhibitor bypassing activity (FEIBA), has been shown to be effective in human plasma ex vivo. ${ }^{10,11}$ Factor VII has been shown to be less effective as a management option. ${ }^{12,13}$ In addition, as the agents are partially protein bound, one could consider dialysis in patients with renal impairment.

Table 4 demonstrates those agents/clinical situations that impact clotting through thrombolysis. ${ }^{1,14}$ Both alteplase and desmoteplase can typically be effectively reversed with either aminocaproic acid or tranexamic acid (depending on which is available in a hospital formulary). Also included in this table are clinical conditions where plasminogen activation and fibrinolysis are hallmarks of the condition (as the tPA-like agents work through plasminogen activation). With acute disseminated intravascular coagulation (DIC) (such as with infection) there is an underlying hypercoagulable state that exists and results in a consumptive coagulopathy. This can then promote bleeding in other areas due to low amount of clotting factors. Primary treatment is reliant upon treating the underlying condition with concurrent supportive care and broad replacement of coagulation factors via fresh frozen plasma (FFP), cryoprecipitate, and platelets. Using fibrinolysis inhibitors in these situations can cause massive thrombosis, because the areas where clotting is occurring can propagate clot if fibrinolysis is not allowed to occur, resulting in ischemia to affected tissues/organs. ${ }^{4}$ For this reason, fibrinolysis inhibitors for reversal of acute DIC are not recommended.

Table 5 demonstrates those coagulopathies that are measured by international normalize ratio (INR). ${ }^{1,6,14}$ They typically relate to the vitamin $\mathrm{K}$ factors or to the synthetic function of the liver if it is substantially impaired. It is recommended to always give vitamin $\mathrm{K}$ for 3 to 5 days when reversing warfarin, as acute reversal strategies can be short lived. At this point in time, PCCs are effective and preferable acute reversal agents for warfarin-associated coagulopathy as opposed to Factor VII. ${ }^{3}$ As with other cases where PCCs are 
Table 1. Factor II (thrombin) and Factor Xinhibition by antithrombin I II activation with reversal agents.

\begin{tabular}{|c|c|c|c|c|c|c|c|}
\hline Anticoagulant & $\begin{array}{l}\text { Half- } \\
\text { life }\end{array}$ & $\begin{array}{l}\text { Duration } \\
\text { of action }\end{array}$ & Reversible & $\begin{array}{l}\text { Reversal } \\
\text { agent }\end{array}$ & Reversal dose & $\begin{array}{l}\text { Reversal } \\
\text { agent half-life }\end{array}$ & $\begin{array}{l}\text { Lab } \\
\text { tests }\end{array}$ \\
\hline Heparin IV* & $\begin{array}{l}1.5 \\
\mathrm{hrs}\end{array}$ & $2.5-4 \mathrm{hrs}$ & Yes & $\begin{array}{l}\text { Protamine } \\
\text { (Class I, } \\
\text { Level B) }\end{array}$ & $\begin{array}{l}1 \mathrm{mg} \text { protamine / } 100 \text { units } \\
\text { heparin given in the past } 2 \text { hours } \\
\text { (max }=50 \mathrm{mg} \text { ) infused over } 10 \\
\text { minutes. } \\
\text { ** If heparin off for } 30-120 \\
\text { minutes use } 1 / 2 \text { the calculated } \\
\text { protamine dose. } \\
\text { ** If heparin off }>120 \text { minutes } \\
\text { and PTT is abnormal then use } 1 / 4 \\
\text { the calculated protamine dose. }\end{array}$ & 7.4 mins & aPTT \\
\hline Heparin SQ* & $6 \mathrm{hrs}$ & $8-12$ hrs & Yes & $\begin{array}{l}\text { Protamine } \\
\text { (Class I, } \\
\text { Level B) }\end{array}$ & $\begin{array}{l}\text { For } 5000 \text { units given }<120 \\
\text { minutes use } 25 \text { mg. } \\
\text { For } 5000 \text { units given }>120 \\
\text { minutes use } 12.5 \mathrm{mg} . \\
\text { Probably no need to treat }>12 \\
\text { hours. } \\
\text { (may need multiple divided doses } \\
\text { because of depot effect) }\end{array}$ & 7.4 mins & $\begin{array}{l}\text { aPTT } \\
\text { ACT }\end{array}$ \\
\hline \multirow[t]{2}{*}{$\begin{array}{l}\text { Fragmin* } \\
\text { (Dalteparin) / } \\
\text { Normiflo* } \\
\text { (Ardeparin) - } \\
\text { LMWH }\end{array}$} & \multirow[t]{2}{*}{$\begin{array}{l}3-5 \\
\text { hrs }\end{array}$} & \multirow[t]{2}{*}{$\begin{array}{l}8-12 \text { hrs, } \\
\text { depending } \\
\text { on renal } \\
\text { function }\end{array}$} & \multirow[t]{2}{*}{ Partially } & $\begin{array}{l}\text { Protamine } \\
\text { (Class I, } \\
\text { Level B) }\end{array}$ & $\begin{array}{l}60 \% \text { reversal: } 1 \mathrm{mg} \text { Protamine / } \\
100 \text { units of dalteparin / } \\
\text { ardeparin given in the past } 2 \\
\text { hours (max }=50 \mathrm{mg} \text { ) infused over } \\
10 \text { minutes if received within the } \\
\text { past } 8 \text { hours. } \\
\text { ** If enoxaparin given }>8 \text { hours } \\
\text { before then give } 1 / 2 \text { the calculated } \\
\text { protamine dose. } \\
\text { Probably no need to treat }>12 \\
\text { hours. }\end{array}$ & 7.4 mins & $\begin{array}{l}\text { Anti- } \\
\text { Factor Xa }\end{array}$ \\
\hline & & & & $\begin{array}{l}\text { Factor } \\
\text { VIla } \\
\text { (Class Ilb, } \\
\text { Level C) }\end{array}$ & $\begin{array}{l}\text { For life-threatening bleeding: } \\
\text { Factor VIla dosing is } 70-90 \\
\mathrm{mcg} / \mathrm{kg} \text { IV with repeat dose of } \\
70-90 \mathrm{mcg} / \mathrm{kg} \text { after } 2 \text { hours if } \\
\text { needed. }\end{array}$ & $2.3 \mathrm{hrs}$ & \\
\hline \multirow[t]{2}{*}{$\begin{array}{l}\text { Lovenox }^{*} \\
\text { (Enoxaparin) - } \\
\text { LMWH }\end{array}$} & \multirow[t]{2}{*}{$7 \mathrm{hrs}$} & \multirow[t]{2}{*}{$\begin{array}{l}8-12 \text { hrs } \\
\text { depending } \\
\text { on renal } \\
\text { function }\end{array}$} & \multirow[t]{2}{*}{ Partially } & $\begin{array}{l}\text { Protamine } \\
\text { (Class I, } \\
\text { Level B) }\end{array}$ & $\begin{array}{l}60 \%-80 \% \text { reversal: } 1 \mathrm{mg} \\
\text { protamine } / 1 \mathrm{mg} \text { of enoxaparin } \\
\text { given in the past } 2 \text { hours (max = } \\
50 \mathrm{mg} \text { ) infused over } 10 \text { minutes if } \\
\text { received within the past } 8 \text { hours. } \\
\text { ** If enoxaparin given }>8 \text { hours } \\
\text { before then give } 1 / 2 \text { the calculated } \\
\text { protamine dose. } \\
\text { Probably no need to treat }>12 \\
\text { hours. }\end{array}$ & 7.4 mins & $\begin{array}{l}\text { Anti- } \\
\text { Factor Xa } \\
+/- \text { ACT }\end{array}$ \\
\hline & & & & $\begin{array}{l}\text { Factor } \\
\text { VIla } \\
\text { (Class Ilb, } \\
\text { Level C) }\end{array}$ & $\begin{array}{l}\text { For life-threatening bleeding: } \\
\text { Factor VIla dosing is } 70-90 \\
\mathrm{mcg} / \mathrm{kg} \text { IV with repeat dose of } \\
70-90 \mathrm{mcg} / \mathrm{kg} \text { after } 2 \text { hours if } \\
\text { needed. }\end{array}$ & $2.3 \mathrm{hrs}$ & \\
\hline $\begin{array}{l}\text { Arixtra** } \\
\text { (Fondaparinux) }\end{array}$ & $\begin{array}{l}17- \\
21 \\
\text { hrs }\end{array}$ & $\begin{array}{l}2-4 \text { days } \\
\text { depending } \\
\text { on renal } \\
\text { function }\end{array}$ & $\begin{array}{l}\text { Limited } \\
\text { Evidence }\end{array}$ & $\begin{array}{l}\text { Factor } \\
\text { VIla } \\
\text { (Class Ilb, } \\
\text { Level C) } \\
\text { Note: } \\
\text { Protamine } \\
\text { NOT } \\
\text { effective }\end{array}$ & $\begin{array}{l}\text { Factor VIla dosing is } 90 \mathrm{mcg} / \mathrm{kg} \\
\text { IV with repeat dose of } 70-90 \\
\mathrm{mcg} / \mathrm{kg} \text { after } 2 \text { hours if needed. }\end{array}$ & $2.3 \mathrm{hrs}$ & $\begin{array}{l}\text { Anti- } \\
\text { Factor Xa }\end{array}$ \\
\hline
\end{tabular}

*Heparin and Low Molecular Weight Heparin have effects on both Factor Xa and Factor II; **Fondaparinux selectively inhibits Factor Xa $\mathrm{IV}=$ intravenous; $\mathrm{SQ}=$ subcutaneous, $\mathrm{LMWH}=$ low molecular weight heparin, $\mathrm{PTT}=$ partial thromboplastin time; aPTT-activated partial thromboplastin time; ACT=activated clotting time; 
Table 2. Direct Factor Xa inhibitors.

\begin{tabular}{|c|c|c|c|c|c|c|c|}
\hline Anticoagulant & $\begin{array}{l}\text { Half- } \\
\text { life }\end{array}$ & $\begin{array}{l}\text { Duration } \\
\text { of action }\end{array}$ & Reversible & $\begin{array}{l}\text { Treatment } \\
\text { strategy }\end{array}$ & Treatment dose & $\begin{array}{l}\text { Treatment agent } \\
\text { half-life }\end{array}$ & $\begin{array}{l}\text { Laboratory } \\
\text { tests }\end{array}$ \\
\hline $\begin{array}{l}\text { Eliquis } \\
\text { (Apixaban) }\end{array}$ & $\begin{array}{l}8-15 \\
\text { hrs }\end{array}$ & $>24 \mathrm{hrs}$ & $\begin{array}{l}\text { Not } \\
\text { currently } \\
\text { reversible }\end{array}$ & $\begin{array}{l}\text { Prothrombin } \\
\text { complex } \\
\text { concentrate } \\
\text { (Class Ilb, Level } \\
\text { C) (No human } \\
\text { studies) }\end{array}$ & $\begin{array}{l}25-50 \text { units/kg IV } \\
\text { with repeat dose if } \\
\text { needed after } 4 \text { hours. } \\
\text { Use lower dose in } \\
\text { non-emergent or } \\
\text { minor hemorrhage } \\
\text { and higher dosage in } \\
\text { moderate to severe } \\
\text { bleeding. }\end{array}$ & $\begin{array}{l}\text { Each factor ranges } \\
\text { from } 4.2-60 \text { hours }\end{array}$ & $\begin{array}{l}\text { Anti-Factor } \\
\text { Xa }\end{array}$ \\
\hline \multirow[t]{2}{*}{$\begin{array}{l}\text { Xarelto } \\
\text { (Rivaroxaban) }\end{array}$} & \multirow[t]{2}{*}{$\begin{array}{l}7-11 \\
\text { hrs }\end{array}$} & \multirow[t]{2}{*}{$\begin{array}{l}8-12 \text { hrs } \\
\text { but Xa } \\
\text { levels } \\
\text { affected } \\
\text { for } 24 \text { hrs }\end{array}$} & $\begin{array}{l}\text { Not } \\
\text { currently } \\
\text { reversible }\end{array}$ & $\begin{array}{l}\text { Prothrombin } \\
\text { complex } \\
\text { concentrate } \\
\text { (Class Ilb, Level } \\
\text { C) }\end{array}$ & $\begin{array}{l}25-50 \text { units/kg IV } \\
\text { with repeat dose if } \\
\text { needed after } 4 \text { hours. } \\
\text { *Use lower dose in } \\
\text { non-emergent or } \\
\text { minor hemorrhage } \\
\text { and higher dosage in } \\
\text { moderate to severe } \\
\text { bleeding. }\end{array}$ & $\begin{array}{l}\text { Each factor ranges } \\
\text { from } 4.2-60 \text { hours }\end{array}$ & \multirow[t]{2}{*}{$\begin{array}{l}\text { Anti-Factor } \\
\text { Xa }\end{array}$} \\
\hline & & & & $\begin{array}{l}\text { Factor VIla } \\
\text { (Animal Studies } \\
\text { Only) }\end{array}$ & $\begin{array}{l}\text { Factor VIla dosing is } \\
90 \mathrm{mcg} / \mathrm{kg} \text { IV with } \\
\text { repeat dose of } 70- \\
90 \mathrm{mcg} / \mathrm{kg} \text { after } 2 \\
\text { hours if needed. }\end{array}$ & 2.3 hours & \\
\hline $\begin{array}{l}\text { Lixiana } \\
\text { (Edoxaban }\end{array}$ & $\begin{array}{l}\text { 9-10 } \\
\text { hrs }\end{array}$ & $>24 \mathrm{hrs}$ & $\begin{array}{l}\text { Not } \\
\text { currently } \\
\text { reversible }\end{array}$ & $\begin{array}{l}\text { Prothrombin } \\
\text { complex } \\
\text { concentrate } \\
\text { (Class Ilb, Level } \\
\text { C) (No human } \\
\text { studies) }\end{array}$ & $\begin{array}{l}25-50 \text { units/kg IV } \\
\text { with repeat dose if } \\
\text { needed after } 4 \text { hours. } \\
\text { *Use lower dose in } \\
\text { non-emergent or } \\
\text { minor hemorrhage } \\
\text { and higher dosage in } \\
\text { moderate to severe } \\
\text { bleeding. }\end{array}$ & $\begin{array}{l}\text { Each factor ranges } \\
\text { from } 4.2-60 \text { hours }\end{array}$ & $\begin{array}{l}\text { Anti-Factor } \\
\text { Xa }\end{array}$ \\
\hline
\end{tabular}

IV=intravenous

utilized, the dose can vary between 20 units $/ \mathrm{kg}$ for minor bleeding to 50 units $/ \mathrm{kg}$ for severe bleeding. Once the initial dose of PCC has been given, one can usually verify correction of INR and then administer FFP as needed to maintain correction. ${ }^{15}$

Table 6 shows those coagulopathies that are related to platelet dysfunction due to medications. ${ }^{1,16-18}$ Note that the laboratory tests listed may be of limited value due to the inherent differences in results between individual patients. Also note that fish oil is not listed, because the exact mechanism of action is not entirely known. It is generally thought to have weak anticoagulant properties. Fish oil affects cell membranes, and its effects are likely permanent with respect to the affected platelets. This means its duration of action could reside in the 5 to 10 day range until new platelets are made, but anticoagulation would also be based on the clearance of fish oil from the body, which is not known. ${ }^{14}$ A commonly employed and supported treatment strategy used with several antiplatelet agents is platelet transfusion. ${ }^{19}$ This is certainly the case for non-steroidal anti-inflammatory drugs, aspirin, and clopidogrel, prasugal, abciximab, cilostazol, and aggrenox. Admittedly, this is an area of active investigation for two reasons: (1) lab work to measure the extent of antiplatelet activity is notoriously inaccurate, and (2) the need for reversal for minor cases has not been validated (nor has the efficacy). However, it is typically agreed that in severe cases of bleeding it is prudent to administer platelet transfusion. In addition, many practitioners will give DDAVP (desmopressin acetate) in addition to platelet transfusion if a procedure is imminent. Antiplatelet agents that may respond to reversal strategies other than platelet transfusion include ticlopidine (can use methylprednisolone) and dipyridamole (where aminophylline may work).

Table 7 shows those coagulopathies that are related to platelet dysfunction from maldevelopment or acquired deficiencies on platelet function. ${ }^{1,14,20}$ The majority of these conditions respond to platelet transfusion with the exception of uremia/ renal failure, which may require dialysis, cryoprecipitate, or desmopressin. It is also worth noting that there is no standardization when it comes to terminology surrounding platelet transfusion and dosage administered. In this paper, a "dose" is typically six random donor platelets (aka, a "six pack").

Table 8 shows the occasional scenario where an immunerelated factor inhibitor is present in the blood. ${ }^{1,14}$ This type of 
Table 3. Direct factor II (thrombin) inhibition with reversal agents.

\begin{tabular}{|c|c|c|c|c|c|c|c|}
\hline Anticoagulant & Half-life & $\begin{array}{l}\text { Duration } \\
\text { of action }\end{array}$ & Reversible & $\begin{array}{l}\text { Treatment } \\
\text { strategy }\end{array}$ & Treatment dose & $\begin{array}{l}\text { Treatment agent } \\
\text { half-life }\end{array}$ & $\begin{array}{l}\text { Laboratory } \\
\text { tests }\end{array}$ \\
\hline $\begin{array}{l}\text { Argatroban } \\
\text { (Argatroban) }\end{array}$ & $\begin{array}{l}45 \\
\text { minutes }\end{array}$ & 51 mins & $\begin{array}{l}\text { Not } \\
\text { currently } \\
\text { reversible }\end{array}$ & $\begin{array}{l}\text { Factor VIla } \\
\text { (Theoretical } \\
\text { only; limited } \\
\text { experience } \\
\text { has not shown } \\
\text { benefit) }\end{array}$ & $\begin{array}{l}\text { Factor VIla dosing is } \\
90 \mathrm{mcg} / \mathrm{kg} \text { IV with } \\
\text { repeat dose of } 70- \\
90 \mathrm{mcg} / \mathrm{kg} \text { after } 2 \\
\text { hrs if needed. }\end{array}$ & $2.3 \mathrm{hrs}$ & $\begin{array}{l}\text { aPTT } \\
\text { INR } \\
\text { TEG } \\
\text { ACT* }^{\star} \\
\text { Thrombin } \\
\text { time }\end{array}$ \\
\hline \multirow[t]{3}{*}{$\begin{array}{l}\text { Pradaxa } \\
\text { (Dabigatran) }\end{array}$} & $\begin{array}{l}\text { Multiple } \\
\text { doses } \\
12-17 \\
\text { hrs }\end{array}$ & & & $\begin{array}{l}\text { Prothrombin } \\
\text { Complex } \\
\text { Concentrate }\end{array}$ & $\begin{array}{l}\text { Prothrombin } \\
\text { Complex } \\
\text { Concentrate dosing } \\
\text { is } 50 \text { units/kg IV } \\
\text { with repeat dose if } \\
\text { needed after } 4 \text { hrs. }\end{array}$ & $4-12 \mathrm{hrs}$ & $\begin{array}{l}\text { TEG } \\
\text { ACT } \\
\text { Thrombin } \\
\text { time } \\
\text { ECT* }^{\star}\end{array}$ \\
\hline & \multirow{2}{*}{$\begin{array}{l}\text { Single } \\
\text { dose } 8 \\
\text { hrs }\end{array}$} & & & FEIBA & $100 \mathrm{U} / \mathrm{kg}$ & $\begin{array}{l}\text { Has Factor II with } \\
\text { half-life of } \sim 72 \\
\text { hrs }\end{array}$ & \\
\hline & & & & $\begin{array}{l}\text { Hemodialysis } \\
\text { (Class Ilb, } \\
\text { Level B) }\end{array}$ & Not applicable & Not applicable & \\
\hline
\end{tabular}

$\begin{array}{ll}\text { Factor VIla } & \text { Factor VIla dosing is } 2.3 \mathrm{hrs} \\ \text { (Animal } & 90 \mathrm{mcg} / \mathrm{kg} \text { IV with } \\ \text { studies only) } & \text { repeat dose of } 70- \\ \begin{array}{l}\text { and has } \\ \text { questionable }\end{array} & 90 \mathrm{mcg} / \mathrm{kg} \text { after } 2 \\ \text { efficacy } & \mathrm{hr} \text { if needed. }\end{array}$

* Laboratory tests minimally useful since values (except possibly ACT, TEG, and antifactor lla) do not necessarily correlate with level of coagulopathy (INR and PTT are often only elevated in supratherapeutic doses, thrombin time is elevated if the drug is present). ECT may be useful for dabigatran (if available). IV=intravenous; aPTT-activated partial thromboplastin time; INR=international normalized ratio; TEG=thromboelastography; $\mathrm{ACT}=$ activated clotting time; $\mathrm{ECT}=$ ecarin clotting time.

coagulopathy is often associated with an elevated aPTT. In such clinical cases, it is unlikely that a specific inhibitor will be identified in a timely matter. In addition, it is unlikely that a specific antidote will be available. Therefore, reversal strategies are broad in scope in hopes of controlling acute bleeding. At this point in time, PCCs are the favored agent. One could also consider Factor VII, aminocaproic acid, or tranexamic acid. Reversal strategies for inhibitor related coagulopathies can be augmented with steroids, intravenous immunoglobulin or plasmapheresis if severe. That said, if a particular factor specific inhibitor can be identified, it may be possible to give that specific factor when developing a reversal strategy.

Table 9 differs from table 8 in that the factor is inherently absent or inadequate in function rather than being blocked by an inhibitor. ${ }^{1,14,21}$ In Von Willebrand's disease, the best treatment options include desmopressin (not in acute hemorrhage), PCC, or Factor VII. In pseudo-Von Willebrand's, platelet transfusion is recommended. In cases of low fibrinogen or Factor XIII, cryoprecipitate is the recommended reversal agent. Lastly, Factor VII was specifically created for use in hemophilia A, while Factor IX concentrate can be given in hemophilia B (or PCC if not available).

\section{Discussion}

The included tables propose succinct and pertinent information intended to allow physicians a quick reference to develop a reversal strategy for a given coagulopathy. Each table lists potential reversal agents in order of preference. For refractory or complicated cases (involving more than one category of coagulopathy), a practitioner may opt to use a combination of agents felt necessary to treat the coagulopathy. It is important to stress that the doses listed for Factor VIIa and PCC are high doses intended for the treatment of severe, life-threatening bleeding. In cases of less severe bleeding, or simple prophylactic reversal, lower doses would be effective. ${ }^{22} \mathrm{~A}$ crucial caveat to the reversal strategies presented in the tables is that there may be variations regarding the availability of certain agents among institutions. It is advisable that every practitioner who may treat a life-threatening intracranial hemorrhage be acutely aware of the reversal agents available within a given institution. Additionally, being aware of (or establishing) coagulopathy reversal protocols (including dosing) for particular clinical scenarios is imperative. This is especially true of PCCs, as they are not all the same. PCCs are diverse reversal agents comprised of varying concentrations of either three or four of the vitamin K-dependent cofactors (II, VII, IX, and X). Each PCC formulation has slightly different concentrations of each of the cofactors: 4-factor concentrates have adequate concentrations of all four of these cofactors, while 3-factor concentrates have much less factor VII. In addition, each PCC can have subtle variations in the relative concentrations of each cofactor present in the drug. It should now be clear that understanding exactly which PCC is available within a particular institution is vital to optimize 
Table 4. Plasminogen activation/fibrinolysis with reversal agents and laboratory tests.*

\begin{tabular}{|c|c|c|c|c|c|c|c|}
\hline $\begin{array}{l}\text { Anticoagulant / } \\
\text { Disease process }\end{array}$ & $\begin{array}{l}\text { Half- } \\
\text { life }\end{array}$ & $\begin{array}{l}\text { Duration } \\
\text { of action }\end{array}$ & Reversible & Reversal agent & Reversal dose & $\begin{array}{l}\text { Reversal agent } \\
\text { half-life }\end{array}$ & $\begin{array}{l}\text { Laboratory } \\
\text { tests }\end{array}$ \\
\hline \multirow[t]{2}{*}{$\begin{array}{l}\text { Activase / } \\
\text { Cathflo } \\
\text { (Alteplase/tPA) }\end{array}$} & \multirow[t]{2}{*}{$\begin{array}{l}26.5- \\
46 \\
\text { mins }\end{array}$} & \multirow[t]{2}{*}{72 mins } & \multirow[t]{2}{*}{ Yes } & $\begin{array}{l}\text { Amicar } \\
\text { (aminocaproic } \\
\text { acid) } \\
\text { or }\end{array}$ & $\begin{array}{l}4-5 \mathrm{~g} \text { load } \\
\text { followed by } 1 \mathrm{~g} / \mathrm{hr} \\
\text { infusion. }\end{array}$ & $4 \mathrm{hrs}$ & \multirow[t]{2}{*}{$\begin{array}{l}\text { D-Dimer } \\
\text { Fibrin split } \\
\text { products }\end{array}$} \\
\hline & & & & Tranexamic acid & 10 mg/kg IV hrs & $2 \mathrm{hrs}$ & \\
\hline \multirow[t]{2}{*}{ Desmoteplase } & \multirow[t]{2}{*}{$4 \mathrm{hrs}$} & \multirow[t]{2}{*}{$6-8 \mathrm{hrs}$} & \multirow[t]{2}{*}{ Yes } & $\begin{array}{l}\text { Amicar } \\
\text { (aminocaproic } \\
\text { acid) or }\end{array}$ & $\begin{array}{l}4-5 \mathrm{~g} \text { load } \\
\text { followed by } 1 \mathrm{~g} / \mathrm{hr} \\
\text { infusion. }\end{array}$ & $4 \mathrm{hrs}$ & \multirow[t]{2}{*}{$\begin{array}{l}\text { D-Dimer } \\
\text { Fibrin split } \\
\text { products }\end{array}$} \\
\hline & & & & Tranexamic acid & 10 mg/kg IV & $2 \mathrm{hrs}$ & \\
\hline \multirow[t]{4}{*}{$\begin{array}{l}\text { Sepsis-related } \\
\text { or } \\
\text { Acute DIC }\end{array}$} & \multirow[t]{4}{*}{$\mathrm{n} / \mathrm{a}$} & \multirow[t]{4}{*}{$\mathrm{n} / \mathrm{a}$} & \multirow[t]{4}{*}{ No } & $\begin{array}{l}\text { Treatment of } \\
\text { underlying cause }\end{array}$ & $\begin{array}{l}\text { n/a but might } \\
\text { include antibiotics } \\
\text { and steroids }\end{array}$ & $\mathrm{n} / \mathrm{a}$ & \\
\hline & & & & Platelets & $\begin{array}{l}1-2 \text { units } / 10 \mathrm{~kg} \\
\text { per day if platelets } \\
<50 \mathrm{~K} / \mathrm{microL}\end{array}$ & $1-2$ days & \\
\hline & & & & FFP & $\begin{array}{l}\text { Variable to keep } \\
\text { INR }<1.5\end{array}$ & $\begin{array}{l}\text { variable } 4-12 \\
\text { hrs }\end{array}$ & \\
\hline & & & & Cryoprecipitate & $\begin{array}{l}10 \text { bags of } \\
\text { American-Red- } \\
\text { Cross-prepared } \\
\text { cryoprecipitate } \\
\text { (roughly } 100-150 \\
\mathrm{~mL} \text { ) to keep goal } \\
\text { fibrinogen level } \\
100-150 .\end{array}$ & 3-5 days & \\
\hline \multirow{2}{*}{$\begin{array}{l}\text { Non-septic, non- } \\
\text { thrombotic } \\
\text { chronic DIC } \\
\text { (promyelocytic } \\
\text { leukemia etc.) } \\
\text { Note use of } \\
\text { fibrinolysis } \\
\text { inhibitors for } \\
\text { reversal in acute } \\
\text { DIC can be fatal } \\
\text { and is not } \\
\text { recommended. }\end{array}$} & \multirow[t]{2}{*}{$\mathrm{n} / \mathrm{a}$} & \multirow[t]{2}{*}{$\mathrm{n} / \mathrm{a}$} & \multirow[t]{2}{*}{ Maybe } & $\begin{array}{l}\text { Amicar } \\
\text { (aminocaproic } \\
\text { acid) or }\end{array}$ & $\begin{array}{l}4-5 \mathrm{~g} \text { load } \\
\text { followed by } 1 \mathrm{~g} / \mathrm{hr} \\
\text { infusion. }\end{array}$ & $4 \mathrm{hrs}$ & \multirow{2}{*}{$\begin{array}{l}\text { aPTT } \\
\text { INR } \\
\text { ACT } \\
\text { D-Dimer } \\
\text { Fibrin split } \\
\text { products }\end{array}$} \\
\hline & & & & Tranexamic acid & $\begin{array}{l}10 \mathrm{mg} / \mathrm{kg} \mathrm{IV} \text { every } \\
6 \mathrm{hrs} \text { (adjust for } \\
\text { renal } \\
\text { insufficiency). }\end{array}$ & $2 \mathrm{hrs}$ & \\
\hline
\end{tabular}


Table 5. Factor II, VII, IX, X (or all except VIII in liver failure) with reversal agents and labs.

\begin{tabular}{|c|c|c|c|c|c|c|c|}
\hline $\begin{array}{l}\text { Anticoagulant / } \\
\text { disease process }\end{array}$ & $\begin{array}{l}\text { Half- } \\
\text { life }\end{array}$ & $\begin{array}{l}\text { Duration } \\
\text { of action }\end{array}$ & Reversible & Reversal agent & Reversal dose & $\begin{array}{l}\text { Reversal agent } \\
\text { half-life }\end{array}$ & $\begin{array}{l}\text { Laboratory } \\
\text { tests }\end{array}$ \\
\hline \multirow[t]{4}{*}{$\begin{array}{l}\text { Coumadin } \\
\text { (warfarin, } \\
\text { jantoven) }\end{array}$} & \multirow[t]{4}{*}{$40 \mathrm{hrs}$} & \multirow[t]{4}{*}{$2-5$ days } & \multirow[t]{4}{*}{ Yes } & $\begin{array}{l}\text { Vitamin K infusion } \\
\text { and } \\
\text { (Class I, Level B) }\end{array}$ & $\begin{array}{l}10 \text { mg IV infusion } \\
\text { (may repeat } \\
\text { PO/IV daily over } \\
3 \text { days). }\end{array}$ & $2 \mathrm{hrs}$ & \multirow[t]{4}{*}{ INR } \\
\hline & & & & $\begin{array}{l}\text { Prothrombin } \\
\text { complex } \\
\text { concentrate } \\
\text { or } \\
\text { (Class Ila, Level B) }\end{array}$ & $\begin{array}{l}\text { Prothrombin } \\
\text { complex } \\
\text { concentrate } \\
\text { dosing is } 20-30 \\
\text { for mild } \\
\text { coagulopathy and } \\
40-50 \text { units/kg IV } \\
\text { for more severe } \\
\text { bleeding. } .^{17} \\
\text { Repeat dose if } \\
\text { needed after } 4 \\
\text { hrs. }\end{array}$ & $\begin{array}{l}\text { Variable 4-12 } \\
\text { hrs }\end{array}$ & \\
\hline & & & & $\begin{array}{l}\text { Factor VIla } \\
\text { (Class Ila, Level B) }\end{array}$ & $\begin{array}{l}\text { Factor VIla dosing } \\
\text { is } 90 \mathrm{mcg} / \mathrm{kg} \text { IV } \\
\text { with repeat dose } \\
\text { of } 70-90 \mathrm{mcg} / \mathrm{kg} \\
\text { after } 2 \mathrm{hrs} \text { if } \\
\text { needed. }\end{array}$ & $2.3 \mathrm{hrs}$ & \\
\hline & & & & $\begin{array}{l}\text { FFP } \\
\text { (Class I, Level B) }\end{array}$ & As needed. & $\begin{array}{l}\text { variable 4-12 } \\
\text { hrs }\end{array}$ & \\
\hline \multirow[t]{5}{*}{ Liver Failure } & \multirow[t]{5}{*}{$\mathrm{n} / \mathrm{a}$} & \multirow[t]{5}{*}{$\mathrm{n} / \mathrm{a}$} & \multirow[t]{5}{*}{ No } & $\begin{array}{l}\text { FFP / } \\
\text { Plasmapheresis } \\
\text { and }\end{array}$ & $\begin{array}{l}\text { As needed (with } \\
\text { plasmapheresis } \\
\text { performed daily } \\
\text { when liver has } \\
\text { limited synthetic } \\
\text { function). }\end{array}$ & $\begin{array}{l}\text { Variable 4-12 } \\
\text { hrs }\end{array}$ & \multirow[t]{5}{*}{ INR } \\
\hline & & & & $\begin{array}{l}\text { Amicar } \\
\text { (aminocaproic } \\
\text { acid) or }\end{array}$ & $\begin{array}{l}4-5 \mathrm{~g} \text { load } \\
\text { followed by } 1 \\
\text { g/hr infusion. }\end{array}$ & $4 \mathrm{hrs}$ & \\
\hline & & & & Tranexamic acid & $\begin{array}{l}10 \mathrm{mg} / \mathrm{kg} \text { IV } \\
\text { every } 6 \text { hours } \\
\text { (adjust for renal } \\
\text { insufficiency). }\end{array}$ & $2 \mathrm{hrs}$ & \\
\hline & & & & $\begin{array}{l}\text { Prothrombin } \\
\text { complex } \\
\text { concentrate } \\
\text { or }\end{array}$ & $\begin{array}{l}\text { Prothrombin } \\
\text { complex } \\
\text { concentrate } \\
\text { dosing is } 50 \\
\text { units/kg IV with } \\
\text { repeat dose if } \\
\text { needed after } 4 \\
\text { hrs. }\end{array}$ & $\begin{array}{l}\text { Variable 4-12 } \\
\text { hrs }\end{array}$ & \\
\hline & & & & Factor VIIa & $\begin{array}{l}\text { Factor VIla dosing } \\
\text { is } 90 \mathrm{mcg} / \mathrm{kg} \text { IV } \\
\text { with repeat dose } \\
\text { of } 70-90 \mathrm{mcg} / \mathrm{kg} \\
\text { after } 2 \mathrm{hrs} \text { if } \\
\text { needed. }\end{array}$ & $2.3 \mathrm{hrs}$ & \\
\hline
\end{tabular}

$\mathrm{IV}=$ intravenous; $\mathrm{PO}=$ orally; FFP=fresh frozen plasma; INR=international normalized ratio 
Table 6. Platelet inhibition with reversal agents and laboratory tests

\begin{tabular}{|c|c|c|c|c|c|c|c|}
\hline Antiplatelet & Half-life & $\begin{array}{l}\text { Duration } \\
\text { of action }\end{array}$ & Reversible & Reversal agent & $\begin{array}{l}\text { Reversal } \\
\text { dose }\end{array}$ & $\begin{array}{l}\text { Reversal } \\
\text { agent } \\
\text { half-life }\end{array}$ & $\begin{array}{l}\text { Laboratory } \\
\text { tests }\end{array}$ \\
\hline NSAIDs & $\begin{array}{l}\text { Varies } \\
\text { based on } \\
\text { drug }\end{array}$ & $<1$ day & $\begin{array}{l}\text { Competitive } \\
\text { cyclooxygenase } \\
\text { binding }\end{array}$ & $\begin{array}{l}\text { Generally not needed } \\
\text { but can use platelets, } \\
\text { desmopressin, or } \\
\text { cryoprecipitate }\end{array}$ & $\begin{array}{l}\text { Not well } \\
\text { documented }\end{array}$ & $\begin{array}{l}\text { Varies } \\
\text { based on } \\
\text { agent } \\
\text { used }\end{array}$ & PFA 100 \\
\hline Aspirin & $2-4.5 \mathrm{hrs}$ & 5-7 days & Partially & Platelets & $\begin{array}{l}1000 \mathrm{ml}- \\
1300 \mathrm{ml}\end{array}$ & $1-2$ days & $\begin{array}{l}\text { PFA } 100 \\
\text { CDP } \\
\text { Collagen/ Epi }\end{array}$ \\
\hline $\begin{array}{l}\text { Plavix } \\
\text { (clopidogrel) }\end{array}$ & $6 \mathrm{hrs}$ & 5-7 days & Partially & Platelets & $\begin{array}{l}1000 \mathrm{ml}- \\
1300 \mathrm{ml}\end{array}$ & $1-2$ days & $\begin{array}{l}\text { Aggregometry } \\
\text { Mapping with } \\
\text { TEG / ADP } \\
\text { Verify Now } \\
\text { System }\end{array}$ \\
\hline $\begin{array}{l}\text { Effient } \\
\text { (prasugrel) }\end{array}$ & $\begin{array}{l}7 \mathrm{hrs} \\
\text { (range 2- } \\
15 \mathrm{hrs} \text { ) }\end{array}$ & 5-9 days & Partially & Platelets & $\begin{array}{l}1000 \mathrm{ml}- \\
1300 \mathrm{ml}\end{array}$ & $1-2$ days & $\begin{array}{l}\text { Aggregometry } \\
\text { Mapping with } \\
\text { TEG / ADP } \\
\text { Verify Now } \\
\text { System }\end{array}$ \\
\hline $\begin{array}{l}\text { Ticlid } \\
\text { (ticlopidine) }\end{array}$ & $12 \mathrm{hrs}$ & $\begin{array}{l}4-10 \\
\text { days }\end{array}$ & Yes & Methylprednisolone & $20 \mathrm{mg}$ IV $\times 1$ & $\begin{array}{l}\text { 18-26 } \\
\text { hrs }\end{array}$ & Bleeding time \\
\hline $\begin{array}{l}\text { Brilinta, } \\
\text { Brilique, Possia } \\
\text { (ticagrelor) }\end{array}$ & $7-8.5 \mathrm{hrs}$ & $\begin{array}{l}24-48 \\
\text { hrs }\end{array}$ & Yes & $\begin{array}{l}\text { Time (platelet } \\
\text { inhibition subsides } \\
\text { competitively) } \\
\text { Platelets? }\end{array}$ & $\begin{array}{l}1000 \mathrm{ml}- \\
1300 \mathrm{ml}\end{array}$ & $1-2$ days & $\begin{array}{l}\text { Aggregometry } \\
\text { Mapping with } \\
\text { TEG / ADP } \\
\text { Verify Now } \\
\text { System }\end{array}$ \\
\hline $\begin{array}{l}\text { Integrilin } \\
\text { (eptifibatide) }\end{array}$ & $2.5 \mathrm{hrs}$ & $2-4 \mathrm{hrs}$ & $\begin{array}{l}\text { Bleeding time } \\
\text { normal within } \\
15-30 \text { min } \\
\text { Platelet } \\
\text { function ( } 60 \% \\
\text { of baseline) } \\
\text { returns after } 2 \\
\text { hours }\end{array}$ & $\begin{array}{l}\text { Platelets maybe } \\
\text { useful after } 1-2 \text { hrs } \\
\text { (before this the } \\
\text { amount of drug } \\
\text { greatly outnumbers } \\
\text { receptors) }\end{array}$ & $\begin{array}{l}1000 \mathrm{ml}- \\
1300 \mathrm{ml}\end{array}$ & $1-2$ days & PFA 100 \\
\hline $\begin{array}{l}\text { Aggrastat } \\
\text { (tirofiban) }\end{array}$ & $2 \mathrm{hrs}$ & $4-8 \mathrm{hrs}$ & $\begin{array}{l}\text { Bleeding time } \\
\text { normal within } 3 \\
\text { hours } \\
\text { Platelet } \\
\text { function (>50\% } \\
\text { of baseline) } \\
\text { returns after } 4 \\
\text { hours }\end{array}$ & $\begin{array}{l}\text { Platelets maybe } \\
\text { useful after } 1-2 \text { hrs } \\
\text { (before this the } \\
\text { amount of drug } \\
\text { greatly outnumbers } \\
\text { receptors) }\end{array}$ & $\begin{array}{l}1000 \mathrm{ml}- \\
1300 \mathrm{ml}\end{array}$ & $1-2$ days & $\begin{array}{l}\text { PFA } 100 \\
\text { ACT }\end{array}$ \\
\hline $\begin{array}{l}\text { Reopro } \\
\text { (abciximab) }\end{array}$ & $\begin{array}{l}10 \text { days in } \\
\text { the } \\
\text { circulation } \\
\text { bound to } \\
\text { platelets }\end{array}$ & $48 \mathrm{hrs}$ & $\begin{array}{l}\text { Platelet } \\
\text { inhibition of } \\
50 \% \text { at } 24 \\
\text { hours; }\end{array}$ & $\begin{array}{l}\text { Platelets (since } \\
\text { plasma half-life is } \\
\text { short) }\end{array}$ & $\begin{array}{l}2000 \mathrm{ml}- \\
2600 \mathrm{ml}\end{array}$ & $1-2$ days & $\begin{array}{l}\text { PFA } 100 \\
\text { ACT }\end{array}$ \\
\hline $\begin{array}{l}\text { Pletal } \\
\text { (cilostazol) }\end{array}$ & $11-13 \mathrm{hrs}$ & $48 \mathrm{hrs}$ & Yes & Platelets & $\begin{array}{l}1000 \mathrm{ml}- \\
1300 \mathrm{ml}\end{array}$ & $1-2$ days & $\begin{array}{l}\text { CDP } \\
\text { Collagen/ Epi }\end{array}$ \\
\hline $\begin{array}{l}\text { Persantine } \\
\text { (dipyridamole) }\end{array}$ & $\begin{array}{l}\text { Alpha (40 } \\
\text { mins) } \\
\text { Beta (10 } \\
\text { hrs) }\end{array}$ & $\begin{array}{l}\text { About } 24 \\
\text { hrs }\end{array}$ & $\begin{array}{l}\text { Yes but of } \\
\text { limited value }\end{array}$ & Aminophylline? & $\begin{array}{l}50-100 \mathrm{mg} \\
\text { IV }\end{array}$ & $7-9 \mathrm{hrs}$ & No labs \\
\hline $\begin{array}{l}\text { Aggrenox } \\
\text { (dipyridamole } \\
+ \text { aspirin) }\end{array}$ & $\begin{array}{l}2-4.5 \mathrm{hrs} \\
\text { based on } \\
\text { aspirin }\end{array}$ & $\begin{array}{l}5-7 \text { days } \\
\text { based on } \\
\text { aspirin }\end{array}$ & Partially & Platelets & $\begin{array}{l}1000 \mathrm{ml}- \\
1300 \mathrm{ml}\end{array}$ & $1-2$ days & $\begin{array}{l}\text { PFA } 100 \\
\text { CDP } \\
\text { Collagen/Epi }\end{array}$ \\
\hline
\end{tabular}


Table 7. Platelet maldevelopment /dysfunction syndromes with reversal agents and laboratory tests.

\begin{tabular}{|c|c|c|c|c|c|c|}
\hline $\begin{array}{l}\text { Platelet } \\
\text { Maldevelopment / } \\
\text { Dysfunction }\end{array}$ & Mechanism & Reversible & Reversal Agent & Reversal Dose & $\begin{array}{l}\text { Reversal Agent } \\
\text { Half-Life }\end{array}$ & $\begin{array}{l}\text { Laboratory } \\
\text { tests }\end{array}$ \\
\hline $\begin{array}{l}\text { Bernard-Soulier } \\
\text { Syndrome }\end{array}$ & $\begin{array}{l}\text { Gplb } \\
\text { glycoprotein } \\
\text { deficiency with } \\
\text { giant platelets }\end{array}$ & Yes & Platelets & $\begin{array}{l}\text { Dose as needed } \\
\text { to keep platelet } \\
\text { count }>100 \mathrm{k}\end{array}$ & $\begin{array}{l}\text { 1-2 days for } \\
\text { transfused } \\
\text { platelets }\end{array}$ & $\begin{array}{l}\text { CBC } \\
\text { PFA } 100 \\
\text { ACT }\end{array}$ \\
\hline $\begin{array}{l}\text { Glanzmann's } \\
\text { Thrombasthenia }\end{array}$ & $\begin{array}{l}\text { Gpllb/llla } \\
\text { integrin failure }\end{array}$ & Yes & Platelets & $\begin{array}{l}\text { Dose as needed } \\
\text { to keep platelet } \\
\text { count }>100 \mathrm{k}\end{array}$ & $\begin{array}{l}\text { 1-2 days for } \\
\text { transfused } \\
\text { platelets }\end{array}$ & $\begin{array}{l}\text { CBC } \\
\text { PFA } 100 \\
\text { ACT }\end{array}$ \\
\hline \multirow[t]{3}{*}{ Thrombocytopenia } & \multirow{3}{*}{$\begin{array}{l}\text { Bone marrow } \\
\text { failure, dilution, } \\
\text { or consumption. } \\
\text { (In liver failure } \\
\text { only additional } \\
\text { platelets may } \\
\text { have a role } \\
\text { besides } \\
\text { replacing } \\
\text { factors.) }\end{array}$} & \multirow[t]{3}{*}{ Yes } & Platelets & $\begin{array}{l}\text { Dose as needed } \\
\text { to keep platelet } \\
\text { count }>100 \mathrm{k}\end{array}$ & $\begin{array}{l}1-2 \text { days for } \\
\text { transfused } \\
\text { platelets }\end{array}$ & \multirow[t]{3}{*}{$\begin{array}{l}\text { CBC } \\
\mathrm{ACT}\end{array}$} \\
\hline & & & Steroids & $\begin{array}{l}\text { Prednisone } \\
1 \mathrm{mg} / \mathrm{kg} / \mathrm{day}\end{array}$ & $1 \mathrm{hr}$ & \\
\hline & & & Splenectomy & $\mathrm{n} / \mathrm{a}$ & $\mathrm{n} / \mathrm{a}$ & \\
\hline \multirow[t]{4}{*}{$\begin{array}{l}\text { Uremia / Renal } \\
\text { Failure }\end{array}$} & \multirow{4}{*}{$\begin{array}{l}\text { Decreased } \\
\text { thromboxane A2 } \\
\text { function and } \\
\text { increased } \\
\text { platelet- } \\
\text { inhibitory } \\
\text { prostaglandin } \\
\text { excess nitric } \\
\text { oxide synthesis }\end{array}$} & \multirow[t]{4}{*}{ Maybe } & Dialysis & $\begin{array}{l}\text { Dialysis is the } \\
\text { preferred } \\
\text { method of } \\
\text { treatment }\end{array}$ & $\mathrm{n} / \mathrm{a}$ & \multirow[t]{4}{*}{$\begin{array}{l}\text { PFA } 100 \\
\text { ACT }\end{array}$} \\
\hline & & & Cryoprecipitate & $\begin{array}{l}10 \text { bags of } \\
\text { American-Red- } \\
\text { Cross-prepared } \\
\text { cryoprecipitate } \\
\text { (roughly 100- } \\
150 \mathrm{~mL} \text { ) }\end{array}$ & $3-5$ days & \\
\hline & & & Desmopressin & $\begin{array}{l}.3 \mathrm{mg} / \mathrm{kg} \text { IV or } \\
\text { SC.or } 300 \mathrm{mg} \\
\text { intranasal. } \\
\text { Repeat in 9-24 } \\
\text { hours as } \\
\text { needed. }\end{array}$ & $1.5-2.5 \mathrm{hrs}$ & \\
\hline & & & $\begin{array}{l}\text { Conjugated } \\
\text { Estrogen }\end{array}$ & $\begin{array}{l}0.6 \mathrm{mg} / \mathrm{kg} \mathrm{IV} \\
\text { daily infusion } \\
\text { for } 5 \text { days } \\
\text { maximum }\end{array}$ & About 13 hrs & \\
\hline
\end{tabular}

Clarification of terminology regarding platelet transfusions:

- Platelet preparations vary from hospital to hospital, making it difficult to suggest a standardized "dose". For the purposes of this paper, it is noted platelets are supplied primarily in two ways: 1) Single donor apheresis concentrates (SDP) and 2) Platelets derived from whole blood, aka random donor platelets (RDP's). RDP's are the most common preparation used in neurosurgery (SDP's are harder and more expensive)

- $\quad$ One pooled concentrate (from oneperson) $=1 \mathrm{RDP}$, which is typically suspended in $40-70 \mathrm{~mL}$ of plasma and contains $0.55-0.8 \times 10^{11}$ platelets and typically raises the platelet count by $5-10 \mathrm{~K}$

$\mathrm{CBC}=$ complete blood count; ; PFA=platelet function testing; $\mathrm{ACT}=$ activated clotting time 
Table 8. Inhibitor related coagulopathieswith reversal agents and laboratory tests.

\begin{tabular}{|c|c|c|c|c|c|}
\hline $\begin{array}{l}\text { Factor } \\
\text { inhibitor }\end{array}$ & Mechanism & Reversible & Reversal agent & Reversal dose & $\begin{array}{l}\text { Reversal agent } \\
\text { half-life }\end{array}$ \\
\hline \multirow[t]{6}{*}{$\begin{array}{l}\text { Immune-related } \\
\text { blood inhibitor }\end{array}$} & \multirow{6}{*}{$\begin{array}{l}\text { Factor is } \\
\text { either } \\
\text { bound or } \\
\text { receptor is } \\
\text { bound } \\
\text { preventing } \\
\text { the factor } \\
\text { from } \\
\text { functioning } \\
\text { effectively }\end{array}$} & \multirow{6}{*}{$\begin{array}{l}\text { No / Maybe } \\
\text { If an inhibitor is } \\
\text { the source of } \\
\text { the } \\
\text { coagulopathy, } \\
\text { specific factor } \\
\text { concentrate } \\
\text { may need to be } \\
\text { augmented } \\
\text { with steroids, } \\
\text { IVIG, and / or } \\
\text { plasmaphoresis. }\end{array}$} & $\begin{array}{l}\text { Factor VIla } \\
\text { or }\end{array}$ & $\begin{array}{l}\text { Factor VIla dosing } \\
\text { is } 90 \mathrm{mcg} / \mathrm{kg} \text { IV } \\
\text { with repeat dose of } \\
70-90 \mathrm{mcg} / \mathrm{kg} \\
\text { after } 2 \mathrm{hrs} \text { if } \\
\text { needed. }\end{array}$ & $2.3 \mathrm{hrs}$ \\
\hline & & & $\begin{array}{l}\text { Prothrombin } \\
\text { complex } \\
\text { concentrate }\end{array}$ & $\begin{array}{l}\text { Prothrombin } \\
\text { complex } \\
\text { concentrate dosing } \\
\text { is } 50 \text { units/kg IV } \\
\text { with repeat dose if } \\
\text { needed after } 4 \text { hrs. }\end{array}$ & $4-12$ hrs \\
\hline & & & $\begin{array}{l}\text { Amicar } \\
\text { (aminocaproic } \\
\text { acid) }\end{array}$ & $\begin{array}{l}4-5 \mathrm{~g} \text { load followed } \\
\text { by } 1 \mathrm{~g} / \mathrm{hr} \text { infusion. }\end{array}$ & $4 \mathrm{hrs}$ \\
\hline & & & or & & \\
\hline & & & Tranexamic acid & $\begin{array}{l}10 \mathrm{mg} / \mathrm{kg} \text { IV every } \\
6 \mathrm{hrs} \text { (adjust for } \\
\text { renal insufficiency). }\end{array}$ & $2 \mathrm{hrs}$ \\
\hline & & & Factor specific & Factor specific & Factor specific \\
\hline
\end{tabular}


Table 9. Factor deficiency related coagulopathies with reversal agents and laboratory tests.

\begin{tabular}{|c|c|c|c|c|c|c|}
\hline $\begin{array}{l}\text { Factor } \\
\text { deficiency }\end{array}$ & Mechanism & Reversible & Reversal agent & Reversal dose & $\begin{array}{l}\text { Reversal } \\
\text { agent half } \\
\text { life }\end{array}$ & $\begin{array}{l}\text { Laboratory } \\
\text { tests }\end{array}$ \\
\hline \multirow[t]{6}{*}{$\begin{array}{l}\text { Von } \\
\text { Willebrand's } \\
\text { Disease (vWD) }\end{array}$} & $\begin{array}{l}\text { Type } 1 \text { - low } \\
\text { production of vWF / } \\
\text { heterozygous }\end{array}$ & vWD Type 1 & $\begin{array}{l}\text { Desmopressin } \\
\text { (not } \\
\text { recommended } \\
\text { for acute } \\
\text { hemorrhage) }\end{array}$ & $\begin{array}{l}.3 \mathrm{mg} / \mathrm{kg} \text { IV or SCor } 300 \\
\mathrm{mg} \text { intranasal. Repeat in } \\
9-24 \text { hrs as needed. }\end{array}$ & $1.5-2.5 \mathrm{hrs}$ & \multirow{6}{*}{$\begin{array}{l}\text { aPTT } \\
\text { Ristocetin } \\
\text { Keep factor VIII } \\
\text { levels above } \\
100 \text { IU/dL with } \\
\text { trough levels } \\
\text { above } 50 \mathrm{IU} / \mathrm{dL} \\
\text { for the next } 7- \\
10 \text { days. Do not } \\
\text { exceed } 200 \mathrm{IU} / \\
\text { dL because of } \\
\text { thrombosis } \\
\text { risk. }\end{array}$} \\
\hline & \multirow{5}{*}{$\begin{array}{l}\text { Type } 2 \text { - normal vWF } \\
\text { levels but abnormal } \\
\text { structure } \\
\text { Type } 2 \mathrm{~A} \text { - decreased } \\
\text { function small structure } \\
\text { Type } 2 \mathrm{~B} \text { - functional } \\
\text { gain due to excessive } \\
\text { platelet binding and } \\
\text { thus vWF consumption } \\
\text { Type } 2 \mathrm{M} \text { - decreased } \\
\text { function large structure } \\
\text { Type } 2 \mathrm{~N} \text { - failure of } \\
\text { vWF to bind factor VIII } \\
\text { Type } 3 \text { - severe with } \\
\text { vWF absence / } \\
\text { homozygous }\end{array}$} & \multirow[t]{5}{*}{$\begin{array}{l}\text { vWD Types } \\
1-3\end{array}$} & $\begin{array}{l}\text { Factor VIII vWF } \\
\text { Concentrate } \\
\text { (Haemosolvate) }\end{array}$ & $\begin{array}{l}50 \text { units } / \mathrm{kg} \text { IV. Repeat } \\
\text { every } 8-24 \text { hrs as needed. }\end{array}$ & $\begin{array}{l}10-11.5 \\
\text { hrs }\end{array}$ & \\
\hline & & & Factor VIIa & $\begin{array}{l}\text { Factor VIla dosing is } 90 \\
\mathrm{mcg} / \mathrm{kg} \text { IV with repeat } \\
\text { dose of } 70-90 \mathrm{mcg} / \mathrm{kg} \\
\text { after } 2 \mathrm{hrs} \text { if needed. }\end{array}$ & $2.3 \mathrm{hrs}$ & \\
\hline & & & $\begin{array}{l}\text { Prothrombin } \\
\text { Complex } \\
\text { Concentrate }\end{array}$ & $\begin{array}{l}\text { Prothrombin complex } \\
\text { concentrate dosing is } 50 \\
\text { units } / \mathrm{kg} \text { IV with repeat } \\
\text { dose if needed after } 4 \mathrm{hrs} \text {. }\end{array}$ & $4-12 \mathrm{hrs}$ & \\
\hline & & & $\begin{array}{l}\text { Amicar } \\
\text { (aminocaproic } \\
\text { acid) or }\end{array}$ & $\begin{array}{l}4-5 \mathrm{~g} \text { load followed by } 1 \\
\text { g/hr infusion. }\end{array}$ & $4 \mathrm{hrs}$ & \\
\hline & & & $\begin{array}{l}\text { Tranexamic } \\
\text { Acid }\end{array}$ & $\begin{array}{l}10 \mathrm{mg} / \mathrm{kg} \text { IV every } 6 \mathrm{hrs} \\
\text { (adjust for renal } \\
\text { insufficiency). }\end{array}$ & $2 \mathrm{hrs}$ & \\
\hline $\begin{array}{l}\text { Pseudo - vWD } \\
\text { Platelet Type }\end{array}$ & $\begin{array}{l}\text { vWF is normal but } \\
\text { binding site on platelets } \\
\text { is abnormal }\end{array}$ & Maybe & Platelets & $\begin{array}{l}\text { ? } 40 \text { pack multidonor } \\
\text { (2000 ml-2600 ml). }\end{array}$ & $1-2$ days & $\begin{array}{l}\text { aPTT } \\
\text { Ristocetin }\end{array}$ \\
\hline $\begin{array}{l}\text { Low } \\
\text { Fibrinogen or } \\
\text { Factor XIII }\end{array}$ & $\begin{array}{l}\text { Dilution, Consumption, } \\
\text { failure to synthesize }\end{array}$ & Yes & Cryoprecipitate & $\begin{array}{l}10 \text { bags of American-Red- } \\
\text { Cross-prepared } \\
\text { cryoprecipitate (roughly } \\
100-150 \mathrm{~mL} \text { ) }\end{array}$ & $3-5$ days & $\begin{array}{l}\text { aPTT } \\
\text { Fibrinogen level } \\
\text { Keep fibrinogen } \\
>100 \mathrm{mg} / \mathrm{dL}\end{array}$ \\
\hline \multirow[t]{4}{*}{ Hemophilia A } & \multirow[t]{4}{*}{$\begin{array}{l}\text { Low production / } \\
\text { absence }\end{array}$} & \multirow[t]{4}{*}{ Yes } & $\begin{array}{l}\text { Factor VIII vWF } \\
\text { Concentrate } \\
\text { (Haemosolvate) }\end{array}$ & $\begin{array}{l}50 \text { units/kg IV. Repeat } \\
\text { every } 8-24 \text { hrs as needed. }\end{array}$ & $\begin{array}{l}10-11.5 \\
\text { hrs }\end{array}$ & \multirow{4}{*}{$\begin{array}{l}\text { aPTT } \\
\text { Factor VIII level } \\
\text { Keep factor VIII } \\
\text { levels above } \\
100 \text { IU/dL with } \\
\text { trough levels } \\
\text { above } 50 \mathrm{IU} / \mathrm{dL} \\
\text { for the next } 7- \\
10 \text { days. Do not } \\
\text { exceed } 200 \\
\text { IU/dL because } \\
\text { of thrombosis } \\
\text { risk. }\end{array}$} \\
\hline & & & Factor VIlaor & $\begin{array}{l}\text { Factor VIla dosing is } 90 \\
\mathrm{mcg} / \mathrm{kg} \text { IV with repeat } \\
\text { dose of } 70-90 \mathrm{mcg} / \mathrm{kg} \\
\text { after } 2 \text { hrs if needed. }\end{array}$ & $2.3 \mathrm{hrs}$ & \\
\hline & & & $\begin{array}{l}\text { Amicar } \\
\text { (aminocaproic } \\
\text { acid) or }\end{array}$ & $\begin{array}{l}4-5 \text { g load followed by } 1 \\
\text { g/hr infusion. }\end{array}$ & $4 \mathrm{hrs}$ & \\
\hline & & & $\begin{array}{l}\text { Tranexamic } \\
\text { Acid }\end{array}$ & $\begin{array}{l}10 \mathrm{mg} / \mathrm{kg} \text { IV every } 6 \text { hours } \\
\text { (adjust for renal } \\
\text { insufficiency). }\end{array}$ & $2 \mathrm{hrs}$ & \\
\hline \multirow[t]{3}{*}{ Hemophilia B } & \multirow[t]{3}{*}{$\begin{array}{l}\text { Low production / } \\
\text { absence }\end{array}$} & \multirow[t]{3}{*}{ Yes } & $\begin{array}{l}\text { Factor IX } \\
\text { Concentrate } \\
\text { (Haemosolvex) } \\
\text { also contains } \\
\text { Factors II, VII, } \\
\text { and X }\end{array}$ & $\begin{array}{l}60-90 \text { units } / \mathrm{kg} \text { IV. Repeat } \\
12-24 \text { hrs as needed. }\end{array}$ & $16-30 \mathrm{hrs}$ & \multirow[t]{3}{*}{$\begin{array}{l}\text { aPTT } \\
\text { Factor IX level }\end{array}$} \\
\hline & & & $\begin{array}{l}\text { Prothrombin } \\
\text { Complex } \\
\text { Concentrate }\end{array}$ & $\begin{array}{l}\text { Prothrombin complex } \\
\text { concentrate dosing is } 50 \\
\text { units } / \mathrm{kg} \text { IV with repeat } \\
\text { dose if needed after } 4 \mathrm{hrs} \text {. }\end{array}$ & $4-12 \mathrm{hrs}$ & \\
\hline & & & Factor VIla & $\begin{array}{l}\text { Factor VIla dosing is } 90 \\
\mathrm{mcg} / \mathrm{kg} \text { IV with repeat } \\
\text { dose of } 70-90 \mathrm{mcg} / \mathrm{kg} \\
\text { after } 2 \mathrm{hrs} \text { if needed. }\end{array}$ & $2.3 \mathrm{hrs}$ & \\
\hline
\end{tabular}

IV=intravenous; aPTT-activated partial thromboplastin time 
treatment strategies. Lastly, the clinician should be aware that many of the reversal agents, such as Factor VIIa and PCC can cause thrombosis and other adverse reactions (eg, in the case of protamine, it is actually an anticoagulant at higher doses).

\section{Conclusion}

A series of nine tables are presented to help neurologists, neurosurgeons, and neurointensivists rapidly determine the best course of action to reverse coagulopathies. This paper intentionally does not comment on which patients qualify for reversal, as there is limited data supporting the use of some reversal agents in specific situations (eg, hemorrhage location, size, clinical status). The tables specifically address the laboratory tests that can assist in quantifying the degree of coagulopathy or treatment progress, the common causes of coagulopathies, the agents used to reverse them, and the duration of action of the offending agents, as well as their effective antidotes. To this point, this technical note should provide a succinct reference for the treatment of critically ill neurosurgical patients with life-threatening bleeding disorders.

\section{References}

1. DRUGDEX ${ }^{\circledR}$ System (electronic version). Truven Health Analytics, Ann Arbor, Michigan, USA. Available at: http:// www.micromedex.com [Last accessed March 31, 2015].

2. Garcia DA, Baglin TP, Weitz JI, Samama MM; American College of Chest Physicians. Parenteral anticoagulants: Antithrombotic Therapy and Prevention of Thrombosis, 9th ed: American College of Chest Physicians Evidence-Based Clinical Practice Guidelines Chest 2012;141:e24S-e43s.

3. Imberti D, Barillari G, Biasioli C, Bianchi M, Contino L, Duce $\mathrm{R}$, Ageno W. Prothrombin complex concentrates for urgent anticoagulation reversal in patients with intracranial haemorrhage. Path Haemost Thromb 2009;36:259-265.

4. Eerenberg ES, Kamphuisen PW, Sijpkens MK, Meijers JC, Buller HR, Levi M. Reversal of rivaroxaban and dabigatran by prothrombin complex concentrate: a randomized, placebocontrolled, crossover study in healthy subjects. Circulation 2011; 124:1573-1579.

5. El Ahmadieh TY, Aoun SG, Daou MR, El Tecle NE, Rahme RJ, Graham RB, Bendok BR. New-generation oral anticoagulants for the prevention of stroke: Implications for neurosurgery. $\mathrm{J}$ Clin Neurosci 2013;20:1350-1356.

6. Ageno W, Gallus AS, Wittkowsky A, Crowther M, Hylek EM, Palareti G. Oral anticoagulant therapy: Antithrombotic Therapy and Prevention of Thrombosis, 9th ed: American College of Chest Physicians Evidence-Based Clinical Practice Guidelines. Chest 2012;141:e44S-88S.

7. van Ryn J, Stangier J, Haertter S, Liesenfeld KH, Wienen W, Feuring M, Clemens A. Dabigatran etexilate--a novel, reversible, oral direct thrombin inhibitor: interpretation of coagulation assays and reversal of anticoagulant activity. Thromb Haemost 2010;103:1116-1127.

8. Weitz JI, Quinlan DJ, Eikelboom JW. Periprocedural management and approach to bleeding in patients taking dabigatran. Circulation 2012;126:2428-2432.

9. Parra MW, Zucker L, Johnson ES, Gullett D, Avila C, Wichner ZA, Kokaram CR. Dabigatran bleed risk with closed head injuries: are we prepared? J Neurosurg 2013;119:760-765.

10. Khoo TL, Weatherburn C, Kershaw G, Reddel CJ, Curnow J, Dunkley $\mathrm{S}$. The use of FEIBA ${ }^{\circledR}$ in the correction of coagulation abnormalities induced by induced by dabigatran. Int J Lab Hematol 2013;35:222-224.
11. Faust AC, Peterson EJ. Management of Dabigatran-associated Intracerebral and intraventricular hemorrhage: a case report. J Emerg Med 2014;46:525-529.

12. Zhou W, Schwarting S, Illanes S, Liesz A, Middelhoff M, Zorn M, Bendszus M, Heiland S, van Ryn J, Veltkamp R. Hemostatic therapy in experimental intracerebral hemorrhage associated with the direct thrombin inhibitor dabigatran. Stroke 2011;42:3594-3599.

13. Garber ST, Sivakumar W, Schmidt RH. Neurosurgical complications of direct thrombin inhibitors - catastrophic hemorrhage after mild traumatic brain injury in a patient receiving dabigatran. J Neurosurg 2012;116:1093-1096.

14. Merck \& Vo., Inc. The Merck manual of diagnosis and therapy. Whitehouse Station, NJ; Merck Sharp \& Dohme Corp: 2009.

15. Bechtel BF, Nunez TC, Lyon JA, Cotton BA, Barrett TW. Treatments for reversing warfarin anticoagulation in patients with acute intracranial hemorrhage: a structured literature review. Int J Emerg Med 2011;41-8.

16. Deeks ED. Ticagrelor: a review of its use in the management of acute coronary syndromes. Drugs 2011;71:909-933.

17. Tcheng JE. Clinical challenges of platelet glycoprotein IIb/IIIa receptor inhibitor therapy: bleeding, reversal, thrombocytopenia, and retreatment. Am Heart J 2000;139:S38-S45.

18. Wallentin L, Becker RC, Budaj A, Cannon CP, Emanuelsson H, Held C, Horrow J, Husted S, James S, Katus H, Mahaffey KW, Scirica BM, Skene A, Steg PG, Storey RF, Harrington RA; PLATO Investigators, Freij A, Thorsén M. Ticagrelor versus clopidogrel in patients with acute coronary syndromes. N Engl J Med 2009;361:1045-1057.

19. Beshay JE, Morgan H, Madden C, Yu W, Sarode R. Emergency reversal of anticoagulation and antiplatelet therapies in neurosurgical patients: a review. J Neurosurg 2010; 112:307-318.

20. Triulzi DJ, Blumberg N. Variability in response to cryoprecipitate treatment for hemostatic defects in uremia. Yale J Biol Med 1990;63:1-7.

21. U.S. Department of Health and Human Services; National Institutes of Health. National Heart Lung and Blood Institute. The diagnosis, evaluation, and management of von Willebrand disease. NIH Publication No. 08-5832. Washington, DC: National Heart, Lung, and Blood Institute; 2007. Available at: http://purl.access.gpo.gov/GPO/ LPS114839 [Last accessed March 31, 2015].

22. Chong CT, Lew TW, Kuperan P, Tan JJ, Tan HL, Kwek TK. Rapid reversal of coagulopathy in warfarin-related intracranial haemorrhages with prothrombin complex concentrates. Anaesth Intensive Care 2010;38:474-480.

\section{Author Affiliations}

Joshua Eric Medow, MD, MS ; Matthew R. Dierks, PharmD'; Eliot Williams, $M D, P h D^{\ddagger}$; J. Christopher Zacko, MD, $M S^{\S}$

${ }^{*}$ Department of Neurosurgery University of Wisconsin Hospital and Clinics, Madison, Wisconsin

${ }^{\prime}$ Department of Pharmacy, University of Wisconsin Hospital and Clinics, Madison, Wisconsin

*Department of Hematology, University of Wisconsin

Hospital and Clinics, Madison, Wisconsin

${ }^{\S}$ Department of Neurosurgery, Penn State Milton S. Hershey Medical Center, Hershey, Pennsylvania 